\title{
Short communication: Genetic aspects of milk differential somatic cell count in Holstein cows: A preliminary analysis
}

\author{
T. Bobbo, M. Penasa,* and M. Cassandro \\ Department of Agronomy, Food, Natural Resources, Animals and Environment (DAFNAE), University of Padova, Viale dell'Università 16, \\ 35020 Legnaro, Padova, Italy
}

\begin{abstract}
The aim of the present study was to assess genetic variation and heritability of a novel indicator of udder health, milk differential somatic cell count (DSCC), which represents the percentage of neutrophils plus lymphocytes in the total somatic cell count (SCC). Furthermore, we estimated genetic and phenotypic correlations of DSCC with other milk traits routinely measured in Italian Holstein cows. Besides DSCC, testday data included milk yield, composition traits (i.e., fat, protein, casein, and lactose percentages), $\mathrm{pH}$, milk urea nitrogen, and SCC. After editing, the final data set included 10,709 test-day records of 5,142 cows in 299 herds. Mean of DSCC was $62.07 \%$, which means that macrophages were approximately $38 \%$ of total SCC. Comparing our results with the literature offered compelling evidence of the importance of acquiring information about the proportion of the different cell types in milk to better define the udder health status. In addition, our analysis revealed, for the first time, that DSCC is a heritable trait, and heritability $(0.08 \pm$ $0.02)$ was higher than that of traditional somatic cell score $(0.04 \pm 0.02)$. Nevertheless, heritability of DSCC is still low compared with milk yield and quality traits. Single-trait analysis within parity showed that DSCC was less heritable in primiparous than in multiparous cows, whereas bivariate analysis confirmed that DSCC and somatic cell score were 2 different traits, as their genetic and phenotypic correlations differed from unity. From a genetic point of view, the DSCC was positively weakly associated with milk yield, lactose percentage, and milk urea nitrogen, and negatively associated with $\mathrm{pH}$. Our findings contributed to the understanding of the genetic background of DSCC and are a precursor to the potential use of DSCC in breeding programs to enhance cow resistance to mastitis. However, further research is needed to determine the weight this novel
\end{abstract}

Received December 3, 2018.

Accepted January 11, 2019.

*Corresponding author: mauro.penasa@unipd.it trait should receive in a selection program aimed to reduce udder health problems.

Key words: differential somatic cell count, mastitis, heritability, genetic correlation, dairy cattle

\section{Short Communication}

The best way to identify IMI in cows is to perform a PCR assay or bacteriological analysis (Nyman et al., 2014). However, these methods are not applicable to routine data collection, as they are time-consuming and expensive. Until now, SCC in milk has been used as an indicator of mastitis (Harmon, 2001), and indirect selection against mastitis using SCC has been implemented in many countries (Weigel and Shook, 2018). In healthy mammary glands, SCC is generally low $(<100,000$ cells $/ \mathrm{mL})$ and macrophages represent the predominant cell type (Lee et al., 1980; Schwarz et al., 2011). When bacteria enter through the teat canal and colonize the mammary gland, the inflammatory response is triggered. In infected udders, SCC increases and the proportion of different cells changes, with neutrophils reaching up to $95 \%$ of total SCC (Kehrli and Shuster, 1994). However, in the early stages of infection, the neutrophil count increases faster than total SCC (Schwarz et al., 2011; Pilla et al., 2012), and thus the knowledge of the proportion of the different cell types in milk, rather than just the overall SCC, could provide valuable information on the inflammatory status of the udder (Pillai et al., 2001; Pilla et al., 2013). The effectiveness of the use of cell differentiation in milk as a method to identify more precisely the inflammatory status of the udder has already been described by Pilla et al. (2012), but only the recent introduction of a novel analyzer (Fossomatic 7 DC, FOSS Analytical A/S, Hillerød, Denmark) has allowed measurement of different cell types in milk in a high-throughput manner using flow cytometry (Damm et al., 2017).

This new advanced milk-testing technology has been implemented in the milk laboratory of the Breeders Association of Veneto Region (Padova, Italy) and allowed the measurement of an additional indicator of udder 
health; that is, differential somatic cell count (DSCC). This novel trait represents the percentage of neutrophils plus lymphocytes in the total SCC; this means that the percentage of macrophages can be calculated as 100 - DSCC. Few insights on DSCC are available in the literature and they are mainly focused on the development of the method of analysis (Damm et al., 2017), the variation of DSCC percentage according to total SCC (Damm et al., 2017), and changes in DSCC during the course of induced mastitis under controlled conditions (Wall et al., 2018). Currently, no information on the genetic aspects of DSCC is available. Investigating the genetic background of DSCC is important to gain knowledge on its potential inclusion in selection programs to enhance mastitis resistance in dairy cattle. Therefore, the aim of the present study was to assess genetic variation and heritability of milk DSCC, and to estimate genetic and phenotypic correlations of DSCC with other milk traits routinely measured in individual samples of Italian Holstein cows.

Test-day milk records collected from January to June 2018 within the national routine milk recording system were provided by the Breeders Association of Veneto Region (Padova, Italy). The data included milk yield $(\mathrm{kg} / \mathrm{d})$, composition traits (fat, protein, casein, and lactose percentages), $\mathrm{pH}$, and MUN (mg/dL) measured using the MilkoScan FT6000 (Foss Electric A/S), SCC (cells $/ \mathrm{mL}$ ), and DSCC (\%) measured using the new Fossomatic 7 DC (FOSS Analytical A/S). Somatic cell count was log-transformed to SCS to achieve normality and homogeneity of variances, according to Ali and Shook (1980). The original database was edited to select cows between 5 and 600 DIM, and with a minimum of 2 test-day records. Contemporary groups (herd test day) were required to have at least 3 observations to be included in the analysis. Only cows with known sire and dam, and sires with at least 5 daughters, were selected for subsequent statistical analysis. After editing, the final data set included 10,709 test-day records of 5,142 cows in 299 herds. Pedigree information was provided by the Italian Holstein Association (ANAFI, Cremona, Italy) and included cows with phenotypic records and all their ancestors up to 6 generations back, for a total of 33,876 animals.

A preliminary investigation of the nongenetic sources of variation of DSCC was conducted by fitting a linear mixed model in SAS (ver. 9.4, SAS Institute Inc., Cary, NC). The model accounted for the fixed effects of herd test day (644 levels) and DIM (13 levels; the first being a class from 5 to $30 \mathrm{~d}$, followed by 11 classes of $30 \mathrm{~d}$ each, and the last being a class $>360 \mathrm{~d}$ ), and parity (3 levels: 1,2, and $\geq 3$ ) and for the random effect of the cow. Single-trait animal models were then run to estimate variance components and heritability of all investigated traits, including the fixed effects of herd test day, DIM, and parity, as described above, and the random effects of additive genetic animal, permanent environment, and the residual. Single-trait animal models were used also to estimate genetic parameters of DSCC within parity, applying the same selection criteria of the data as above. Bivariate animal models were run to estimate genetic and phenotypic correlations of DSCC and SCS with the other milk traits, and between DSCC and SCS. Fixed and random effects were the same as those included in univariate analyses. All the genetic analyses were performed using VCE software, version 6.0 (Neumaier and Groeneveld, 1998).

Descriptive statistics of milk yield, composition, $\mathrm{pH}, \mathrm{MUN}$, and SCS (Table 1) were consistent with the official statistics reported by ANAFI (2017) and comparable with findings of Tiezzi et al. (2013) for the same breed. Heritability of milk yield was $0.08 \pm 0.03$, and heritabilities of milk composition and $\mathrm{pH}$ ranged from $0.10 \pm 0.02(\mathrm{MUN})$ to $0.35 \pm 0.04(\mathrm{pH}$; Table 1$)$. Our results were mostly in agreement with findings reported in the literature (Cassandro et al., 2008; Tiezzi et al., 2013), although heritability of fat percentage in the present study $(0.17 \pm 0.03)$ was lower than that $(0.39 \pm 0.04)$ estimated by Cassandro et al. (2008), and heritability of $\mathrm{pH}$ was higher than the estimates of $0.21 \pm 0.04$ and $0.26 \pm 0.03$ assessed by Cassandro et al. (2008) and Tiezzi et al. (2013), respectively. As expected, SCS was less heritable $(0.04 \pm 0.02)$ than other milk traits (Table 1).

Differential SCC averaged $62.07 \%$, which means that macrophages were approximately $38 \%$ of the total SCC (Table 1). Our results differed to some extent from those of Damm et al. (2017), who analyzed 655 routine DHI milk samples collected from Canada, Denmark, France, and New Zealand to test the robustness of the method under different conditions. Damm et al. (2017) reported means of DSCC that ranged from 72.68 (Denmark, $\mathrm{n}=153$ ) to $76.12 \%$ (Canada, $\mathrm{n}=158$ ); nevertheless, the minimum value of DSCC (20\%) obtained by Damm et al. (2017) was much greater than that found in our study (4.5\%), whereas the same maximum value was observed in both studies (96\%). Interestingly, similar mean SCC were obtained in the 2 studies: 231,000 cells/mL (with DHI SCC between 8,000 and 7,085,000 cells $/ \mathrm{mL}$ ) in Damm et al. (2017) and 205,000 cells $/ \mathrm{mL}$ (with test-day SCC between 2,000 and 8,421,000 cells/ $\mathrm{mL}$ ) in the present study. These results offer compelling evidence of the importance of acquiring information about the proportion of the different cell types in milk, rather than just the overall SCC, to better define udder health status. In addition, our analysis revealed, for the 
Table 1. Descriptive statistics, permanent environmental variance $\left(\sigma_{p e}^{2}\right)$, residual variance $\left(\sigma_{e}^{2}\right)$, estimated heritability $\left(\mathrm{h}^{2} ; \mathrm{SE}\right.$ within parentheses), and coefficient of additive genetic variation $\left(\mathrm{CV}_{\mathrm{a}}\right)$ of test-day milk yield, milk composition, $\mathrm{pH}, \mathrm{MUN}$, SCS, and differential somatic cell count (DSCC) in Holstein cattle $(\mathrm{n}=10,709)$

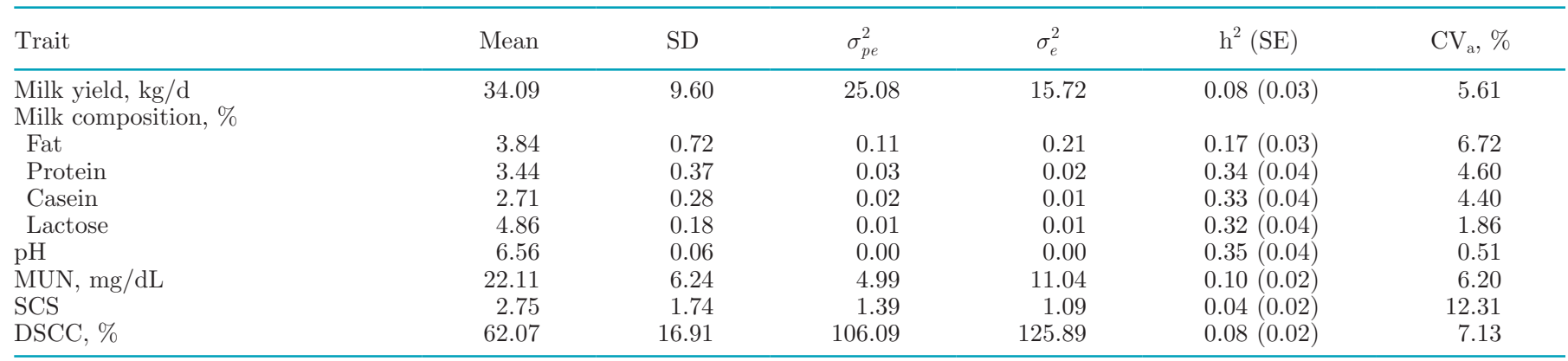

first time, that DSCC is a heritable trait and its heritability is higher than that of traditional SCS $(0.08 \pm$ 0.02 vs. $0.04 \pm 0.02$; Table 1$)$. Nevertheless, heritability of DSCC is still low compared with milk production traits, which is expected for health traits.

Heritability of DSCC was also estimated within parity, and results showed that DSCC was less heritable in primiparous $(0.04 \pm 0.04)$ than in multiparous cows $(0.14 \pm 0.08$ in second-parity and $0.10 \pm 0.06$ in thirdand later-parity animals; Table 2). Similarly, heritability of SCS increased with parity, and larger estimates in multiparous cows suggested that SCS in younger and older animals could be considered genetically different traits, and that the most important mechanisms of defense against IMI at older ages were genetically more variable (Coffey et al., 1985). In accordance with this hypothesis, greater coefficients of additive genetic variation were obtained for DSCC in multiparous than primiparous cows (Table 2).

As ours is the first study to estimate genetic parameters of DSCC, comparisons can be made only with SCC, which is the standard indicator of mastitis (Harmon, 2001). Nevertheless, DSCC and SCS are different traits, as their genetic and phenotypic correlations differed from unity (0.66; Table 3$)$. Results from bivariate analysis corroborated the assumption that an increase of milk SCS is associated with a decrease of milk production (negative phenotypic correlation) and that high-producing cows could be more susceptible to mastitis (unfavorable genetic correlation; Table 3).
Greater susceptibility to mastitis of high-producing cows was hypothesized also by Haile-Mariam et al. (2001) in first-lactation Australian Holsteins, and positive genetic correlations between test-day milk yield and SCC were previously reported by Koivula et al. (2005) in first-lactation Finnish Ayrshires before $(0.17 \pm 0.09)$ and after $(0.25 \pm 0.08)$ clinical mastitis. Nevertheless, negative or near-zero genetic correlations were estimated in the second lactation both by Haile-Mariam et al. (2001) and Koivula et al. (2005), meaning that mastitis causes an increase of SCC and damages the udder, resulting in reduced milk production. Phenotypic correlations of SCS with fat, protein, and casein percentages were close to zero (0.05 to 0.08), and their genetic counterparts were weak $(0.11 \pm 0.18$ to $0.21 \pm 0.20$; Table 3$)$. Our results confirmed previous findings by Carlén et al. (2004) in Swedish Holsteins, who reported positive genetic correlations of SCS with fat yield (from $0.17 \pm 0.04$ in first lactation to $0.02 \pm$ 0.11 in third lactation) and protein yield (from $0.23 \pm$ 0.04 in first lactation to $0.13 \pm 0.11$ in third lactation). The DSCC was phenotypically uncorrelated with milk yield, composition, $\mathrm{pH}$, and MUN ( -0.05 to 0.03 ) and, from a genetic point of view, the DSCC was almost uncorrelated with fat, protein, and casein percentages and weakly associated with milk yield $(0.15 \pm 0.22$; Table $3)$. Lactose percentage was negatively correlated with SCS, both at the phenotypic $(-0.26)$ and genetic level $(-0.34 \pm 0.15)$, in agreement with findings of Miglior et al. (2007) and Stoop et al. (2007), whereas a positive

Table 2. Descriptive statistics, permanent environmental variance $\left(\sigma_{p e}^{2}\right)$, residual variance $\left(\sigma_{e}^{2}\right)$, estimated heritability ( $\mathrm{h}^{2} ; \mathrm{SE}$ within parentheses), and coefficient of additive genetic variation $\left(\mathrm{CV}_{\mathrm{a}}\right)$ of test-day differential somatic cell count (DSCC) by parity

\begin{tabular}{lcccrrrr}
\hline Parity & No. of test-day records & Mean & SD & $\sigma_{p e}^{2}$ & $\sigma_{e}^{2}$ & $h^{2}(\mathrm{SE})$ & $\mathrm{CV}_{\mathrm{a}}, \%$ \\
\hline 1 & 3,866 & 62.43 & 16.51 & 106.85 & 119.69 & $0.04(0.04)$ & 4.73 \\
2 & 2,308 & 59.65 & 17.11 & 73.92 & 147.06 & $0.14(0.08)$ & 9.95 \\
$\geq 3$ & 2,571 & 64.13 & 17.24 & 122.34 & 119.13 & $0.10(0.06)$ & 8.07 \\
\hline
\end{tabular}


Table 3. Genetic ( $\mathrm{r}_{\mathrm{a}}$; SE within parentheses) and phenotypic correlations $\left(\mathrm{r}_{\mathrm{p}}\right)$ of test-day differential somatic cell count (DSCC) and SCS with milk yield, composition, pH, and MUN

\begin{tabular}{lccccc}
\hline & \multicolumn{2}{c}{ DSCC } & & \multicolumn{2}{c}{ SCS } \\
\cline { 2 - 3 } \cline { 5 - 6 } Trait & $\mathrm{r}_{\mathrm{a}}(\mathrm{SE})$ & $\mathrm{r}_{\mathrm{p}}$ & & $\mathrm{r}_{\mathrm{a}}(\mathrm{SE})$ & $\mathrm{r}_{\mathrm{p}}$ \\
\hline Milk yield & $0.15(0.22)$ & 0.03 & & $0.25(0.28)$ & -0.14 \\
Milk composition & & & & $0.21(0.20)$ & 0.08 \\
Fat & $0.06(0.16)$ & -0.03 & & $0.17(0.17)$ & 0.08 \\
Protein & $0.02(0.14)$ & -0.02 & & $0.11(0.18)$ & 0.05 \\
Casein & $0.03(0.14)$ & -0.02 & & $-0.34(0.15)$ & -0.26 \\
Lactose & $0.16(0.15)$ & -0.05 & & $-0.29(0.15)$ & -0.07 \\
pH & $-0.14(0.14)$ & -0.04 & & $0.13(0.19)$ & -0.10 \\
MUN & $0.16(0.15)$ & -0.04 & & - \\
SCS & $0.66(0.13)$ & 0.66 & & -
\end{tabular}

weak genetic correlation was estimated between lactose percentage and DSCC $(0.16 \pm 0.15$; Table 3$)$. Genetic associations of SCS and DSCC with $\mathrm{pH}$ were negative $(-0.29 \pm 0.15$ and $-0.14 \pm 0.14$, respectively $)$, and with MUN were positive and weak $(0.13 \pm 0.19$ and $0.16 \pm$ 0.15 , respectively; Table 3$)$. A negative genetic correlation (-0.19) between MUN and SCS was estimated by Miglior et al. (2007), whereas Stoop et al. (2007) assessed a strong positive genetic correlation (0.85 \pm $0.19)$ between the 2 traits, underlying the discrepancy between studies and the uncertainty of the results.

In conclusion, our study supported the importance of gaining knowledge on the proportion of the different cell types in milk, rather than just the overall SCC, to have a better indicator of mastitis. Indeed, DSCC is a powerful tool to help farmers make better decisions to reduce the use of antimicrobials on the farm. Our findings highlighted that DSCC has additive genetic variation that is potentially exploitable in breeding programs aimed to select against mastitis in combination with the traditional SCS. Further research is needed to confirm the current results, especially on a larger data set to reduce the high standard errors of the estimates found in this preliminary analysis, and to assess the proper weight the DSCC should receive in a selection program aimed to reduce udder health problems.

\section{ACKNOWLEDGMENTS}

The authors thank the Italian Breeders Association (AIA, Roma, Italy) and the University of Padova, Italy (project DOR1980972/19) for funding the study, the Italian Holstein Association (Cremona, Italy) for providing pedigree information, and the Breeders Association of Veneto Region (ARAV, Padova, Italy) for providing test-day data. The authors gratefully acknowledge Sofia Ton (ARAV, Padova, Italy) for technical support.

\section{REFERENCES}

Ali, A. K. A., and G. E. Shook. 1980. An optimum transformation for somatic cell concentration in milk. J. Dairy Sci. 63:487-490. https: //doi.org/10.3168/jds.S0022-0302(80)82959-6.

ANAFI. 2017. ANAFI Statistics. Accessed Nov. 5, 2018. http://www .anafi.it/english/.

Carlén, E., E. Strandberg, and A. Roth. 2004. Genetic parameters for clinical mastitis, somatic cell score, and production in the first three lactations of Swedish Holstein cows. J. Dairy Sci. 87:3062 3070. https://doi.org/10.3168/jds.S0022-0302(04)73439-6.

Cassandro, M., A. Comin, M. Ojala, R. Dal Zotto, M. De Marchi, L. Gallo, P. Carnier, and G. Bittante. 2008. Genetic parameters of milk coagulation properties and their relationships with milk yield and quality traits in Italian Holstein cows. J. Dairy Sci. 91:371376. https://doi.org/10.3168/jds.2007-0308.

Coffey, E. M., W. E. Vinson, and R. E. Pearson. 1985. Heritabilities for lactation average of somatic cell counts in first, second, and third or later parities. J. Dairy Sci. 68:3360-3362. https://doi.org/ 10.3168/jds.S0022-0302(85)81247-9.

Damm, M., C. Holm, M. Blaabjerg, M. Bro Nielsen, and D. Schwarz. 2017. Differential somatic cell count-A novel method for routine mastitis screening in the frame of Dairy Herd Improvement testing programs. J. Dairy Sci. 100:4926-4940. https://doi.org/10.3168/ jds.2016-12409.

Haile-Mariam, M., P. J. Bowman, and M. E. Goddard. 2001. Genetic and environmental correlations between test-day somatic cell count and milk yield traits. Livest. Prod. Sci. 73:1-13. https://doi .org/10.1016/S0301-6226(01)00232-9.

Harmon, R. J. 2001. Somatic cell counts: A primer. Pages 3-9 in Proc. Natl. Mastitis Coun. 40th Annual Meeting, Feb. 11-14, 2001 Reno, NV.

Kehrli, M. E., and D. E. Shuster. 1994. Factors affecting milk somatic cells and their role in health of the bovine mammary gland. J. Dairy Sci. 77:619-627. https://doi.org/10.3168/jds.S0022 -0302(94)76992-7.

Koivula, M., E. A. Mäntysaari, E. Negussie, and T. Serenius. 2005. Genetic and phenotypic relationship among milk yield and somatic cell count before and after clinical mastitis. J. Dairy Sci. 88:827833. https://doi.org/10.3168/jds.S0022-0302(05)72747-8.

Lee, C. S., F. B. P. Wooding, and P. Kemp. 1980. Identification properties and differential counts of cell populations using electron microscopy of dry cow secretions, colostrum and milk from normal cows. J. Dairy Res. 47:39-50. https://doi.org/10.1017/ S0022029900020860.

Miglior, F., A. Sewalem, J. Jamrozik, J. Bohmanova, D. M. Lefebvre, and R. K. Moore. 2007. Genetic analysis of milk urea nitrogen and lactose and their relationships with other production traits in Canadian Holstein cattle. J. Dairy Sci. 90:2468-2479. https://doi .org/10.3168/jds.2006-487. 
Neumaier, A., and E. Groeneveld. 1998. Restricted maximum likelihood estimation of covariances in sparse linear models. Genet. Sel. Evol. 30:3-26.

Nyman, A.-K., K. Persson Waller, T. W. Bennedsgaard, T. Larsen, and U. Emanuelson. 2014. Associations of udder-health indicators with cow factors and with intramammary infection in dairy cows. J. Dairy Sci. 97:5459-5473. https://doi.org/10.3168/jds.2013 -7885 .

Pilla, R., M. Malvisi, G. Snel, D. Schwarz, S. König, C.-P. Czerny, and R. Piccinini. 2013. Differential cell count as an alternative method to diagnose dairy cow mastitis. J. Dairy Sci. 96:1653-1660. https: //doi.org/10.3168/jds.2012-6298.

Pilla, R., D. Schwarz, S. König, and R. Piccinini. 2012. Microscopic differential cell counting to identify inflammatory reactions in dairy cow quarter milk samples. J. Dairy Sci. 95:4410-4420. https: //doi.org/10.3168/jds.2012-5331.

Pillai, S. R., E. Kunze, L. M. Sordillo, and B. M. Jayarao. 2001. Application of differential inflammatory cell count as a tool to monitor udder health. J. Dairy Sci. 84:1413-1420. https://doi.org/10.3168/ jds.S0022-0302(01)70173-7.

Schwarz, D., U. S. Diesterbeck, S. König, K. Brügemann, K. Schlez, M. Zschöck, W. Wolter, and C.-P. Czerny. 2011. Microscopic dif- ferential cell counts in milk for the evaluation of inflammatory reactions in clinically healthy and subclinically infected bovine mammary glands. J. Dairy Res. 78:448-455. https://doi.org/10 $.1017 /$ S0022029911000574.

Stoop, W. M., H. Bovenhuis, and J. A. M. van Arendonk. 2007. Genetic parameters for milk urea nitrogen in relation to milk production traits. J. Dairy Sci. 90:1981-1986. https://doi.org/10.3168/ jds.2006-434.

Tiezzi, F., D. Pretto, M. De Marchi, M. Penasa, and M. Cassandro. 2013. Heritability and repeatability of milk coagulation properties predicted by mid-infrared spectroscopy during routine data recording, and their relationships with milk yield and quality traits. Animal 7:1592-1599. https://doi.org/10.1017/S1751731113001195.

Wall, S. K., O. Wellnitz, R. Bruckmaier, and D. Schwarz. 2018. Differential somatic cell count in milk before, during, and after artificially induced immune reactions of the mammary gland. J. Dairy Sci. 101:5362-5373. https://doi.org/10.3168/jds.2017-14152.

Weigel, K. A., and G. E. Shook. 2018. Genetic selection for mastitis resistance. Vet. Clin. North Am. Food Anim. Pract. 34:457-472. https://doi.org/10.1016/j.cvfa.2018.07.001. 